\title{
Prostaglandin protects against bile salt induced increases in proton permeation of duodenal brush border membrane
}

\author{
D Zhao, B H Hirst
}

\begin{abstract}
A direct protective action of prostaglandin on luminal cell membranes was investigated by preincubating rabbit duodenal brush border membrane vesicles with prostaglandin $\mathbf{E}_{2}$ $\left(\mathrm{PGE}_{2}\right)$ before incubation with bile salts. Membrane perturbation was assessed by measuring the net proton permeability $\left(\mathbf{P}_{\text {net }}\right)$. Bile salts (deoxycholate, glycodeoxycholate, and taurodeoxycholate; 0.1-1.0 mmol//) resulted in concentration dependent increases in $P_{\text {net }}$ : from (mean (SE)) $5.42(0 \cdot 17)(n=20)$ to $8.44(0.24) \times 10^{-4}(\mathrm{n}=13) \mathrm{cm} / \mathrm{s}$ with $0.5 \mathrm{mmol} / \mathrm{l}$ deoxycholate. $\mathrm{PGE}_{2}, 10^{-8}-10^{-6} \mathrm{~mol} / \mathrm{l}$, when added alone had no effect on $P_{\text {net }}: 5.41(0.21)$ $\times 10^{-4}(\mathrm{n}=14) \mathrm{cm} / \mathrm{s}$ with $10^{-6} \mathrm{M} \mathrm{PGE}_{2}$. When duodenal brush border membranes were preincubated with $\mathrm{PGE}_{2}, 10^{-7}-10^{-6} \mathrm{~mol} / \mathrm{l}$, however, the bile salt induced increase in $P_{\text {net }}$ was significantly reduced: $7 \cdot 22(0 \cdot 18) \times 10^{-4}(n=13) \mathrm{cm} / \mathrm{s}$ with $10^{-7} \mathrm{~mol} / 1 \mathrm{PGE}_{2}$ and $0.5 \mathrm{mmol} / 1$ deoxycholate. These findings indicate that $\mathrm{PGE}_{2}$ exerts a direct protective action on duodenal luminal membranes.
\end{abstract}

The mechanism(s) by which prostaglandins protect the gastrointestinal mucosa against damaging agents ${ }^{12}$ is still unclear, despite considerable scientific effort. Prostaglandins show many activities which may contribute towards protective mechanisms. ${ }^{3-6}$ At the vascular level maintenance of endothelial integrity and mucosal blood flow is a recognised gastric protective mechanism. ${ }^{7-9}$ Recent evidence also points to a direct cellular protective action. ${ }^{10-15}$

We have established the use of apical membrane vesicles isolated from the upper gastrointestinal tract as model systems for studying the mechanism of action of several damaging agents, including ethanol and bile salts. ${ }^{16-19}$ Increased apical membrane permeability to protons is a sensitive indicator of the action of these damaging agents. ${ }^{1819}$ In the present study we have investigated whether prostaglandin $\mathrm{E}_{2}\left(\mathrm{PGE}_{2}\right)$ has a direct protective action on upper gastrointestinal luminal membranes by studying their ability to reduce the increase in proton permeability induced by bile salts in rabbit duodenal brush border membrane vesicles.

Physiological Sciences, University of Newcastle university of Newcasth School, Newcastle upon Tyne NE2 4HH

D Zhao

B H Hirst

Correspondence to: Dr Barry H Hirst.

Accepted for publication 17 July 1990
Duodenal brush border membrane vesicles were prepared from young New Zealand white rabbits by a slight modification of the method of Kessler

\section{Methods}

et $a l,,^{20}$ as described previously. ${ }^{16}{ }^{19}$ The enclosed volume of the vesicles was determined as the retention of $\left[{ }^{14} \mathrm{C}\right]$ glucose at equilibrium $(45 \mathrm{~min})$ in a solution containing $150 \mathrm{mmol} / 1 \mathrm{NaCl}$ and $0 \cdot 2$ $\mathrm{mmol} / \mathrm{l}$ glucose, by a rapid filtration technique, and expressed as $\mu \mathrm{l} / \mathrm{mg}$ membrane protein. ${ }^{1619}$ Protein was determined by the method of Bradford $^{21}$ using $\gamma$ globulin (Cohn fraction IV) as standard.

The net $\mathrm{H}^{+} / \mathrm{OH}^{-}$permeability $\left(\mathrm{P}_{\text {net }}\right)$ of brush border membrane vesicles was determined as described by Wilkes et al..$^{18}$ Membrane vesicles were incubated on ice for 25 minutes in a $\mathrm{pH} 6.5$ solution $\left(150 \mathrm{mmol} / \mathrm{l} \mathrm{K} \mathrm{K}^{+}\right.$gluconate, $10 \mathrm{mmol} / \mathrm{l}$ hydroxyethylpiperazine-ethanesulphonic acid (HEPES)/Tris) containing $4 \mu \mathrm{mol} / \mathrm{l}$ valinomycin (to voltage-clamp the vesicles), with varying concentrations of bile salts or $\mathrm{PGE}_{2}$, or both. Proton permeation was monitored by diluting vesicles in $150 \mathrm{mmol} / 1 \mathrm{~K}^{+}$gluconate, $6 \mu \mathrm{mol} / \mathrm{l}$ acridine orange, $10 \mathrm{mmol} / \mathrm{l} \mathrm{HEPES} / \mathrm{Tris}$ at $\mathrm{pH}$ $8 \cdot 0$. The fluorescence signal from the acridine

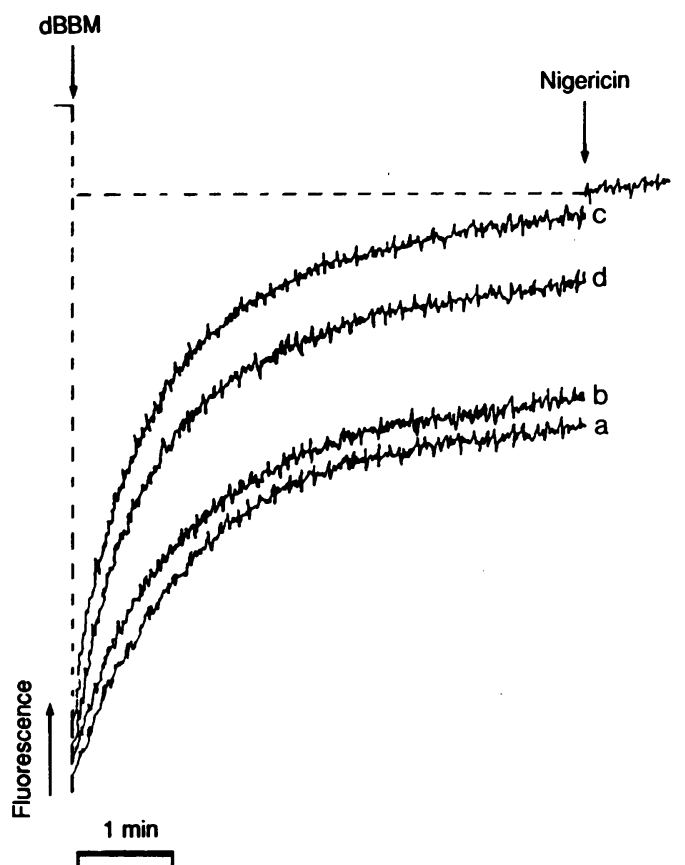

Figure 1: The effect of $P G E_{2}$ on bile salt induced increase in proton permeation in duodenal brush border membrane vesicles. On addition of vesicles equilibrated at pH 6.5 to a solution containing acridine orange, at $\mathrm{pH} 8 \cdot 0$, fluorescence $\left(\lambda_{e x} 490 \mathrm{~nm}, \lambda_{\mathrm{m}} 522 \mathrm{~nm}\right)$ quenching is observed due to accumulation of acridine orange into the acidic intravesicular compartment. As the $\mathrm{pH}$ gradient is dissipated, quenching is reduced. Addition of nigericin, a $\mathrm{K}^{+} / \mathrm{H}^{+}$ionophore, completely dissipates the $\mathrm{pH}$ gradient. The traces illustrate experiments with vesicles preincubated $(a)$ under control conditions, (b) with $P G E, 10^{-7}$ molll, (c) with deoxycholate $0.5 \mathrm{mmol} / \mathrm{l}$, and (d) with $P G E_{2} 10^{-7} \mathrm{~mol} / \mathrm{l}$, plus deoxycholate 0.5 mmolll. $d B B M=$ duodenal brush border membrane vesicles. 
orange (excitation $490 \mathrm{~nm}$; emission $522 \mathrm{~nm}$ ) was monitored in a Perkin Elmer LS-5 spectrofluorimeter fitted with a cuvette holder maintained at $20^{\circ} \mathrm{C}$. The rate of permeation of protons out of the vesicles follows simple first order kinetics, ${ }^{18}$ and was quantified by fitting the recovery of acridine orange fluorescence quenching as a function of time with a non-linear regression analysis procedure (Enzfitter, Elsevier Biosoft). ${ }^{19}$ The net flux of proton and hydroxide ions $\left(\mathbf{P}_{\text {net }}\right)$ was calculated from the exponential time constant for recovery of acridine orange fluorescence $(\tau)$ by

$$
P_{\text {net }}=P_{\mathrm{H}}+P_{\text {oH }}=\frac{r \cdot \beta_{\text {end }}+\beta_{\text {ex }}}{3 \tau\left[\mathrm{H}^{+}\right]_{\mathrm{i}} \cdot \ln 10},
$$

using the constants derived by Wilkes et $a l,{ }^{18}$ and where $r$ is the mean vesicle radius $(0 \cdot 1 \mu \mathrm{m}), \beta_{\text {end }}$ the endogenous buffer capacity of the vesicles ( 45 $\mathrm{mmol} / \mathrm{l} / \mathrm{pH}$ unit), $\beta_{\mathrm{ex}}$ the external buffer capacity of the solution, and $\left[\mathrm{H}^{+}\right]_{i}$ the concentration of free protons within the vesicle interior.

BILE SALT AND PROSTAGLANDIN $\mathrm{E}_{2}$ TREATMENT Deoxycholate, glycodeoxycholate, and taurodeoxycholate acid (Steraloids) and $\mathrm{PGE}_{2}$ (Sigma) were made up fresh each day and final $\mathrm{pH}$ adjusted after sonication. The vesicles were preincubated with $\mathrm{PGE}_{2}$ for five minutes before the addition of bile salts and incubated for a further 20 minutes before analysis. ${ }^{19}$ Appropriate controls without bile salts or without $\mathrm{PGE}_{2}$ were included.

\section{STATISTICAL ANALYSIS}

Significance of difference between mean values was investigated by analysis of variance followed by Student's $t$ test. Significance was set at $\mathrm{p}<0.05$, and results are expressed as mean (SE) (n).

\section{Results}

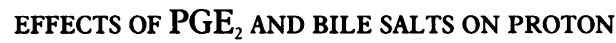
PERMEATION IN DUODENAL BRUSH BORDER MEMBRANE VESICLES

Under control condition without bile salts or $\mathrm{PGE}_{2}$, the mean net proton/hydroxide permeability coefficient $\left(\mathrm{P}_{\text {net }}\right)$ was (mean (SE)) 5.42 $(0 \cdot 17) \times 10^{-4}(\mathrm{n}=20) \mathrm{cm} / \mathrm{s}$. The rate of proton permeation, as determined by the rate of recovery of acridine orange fluorescence quenching, was accelerated by the bile salts (Fig 1 ). $P_{\text {net }}$ was increased in a concentration dependent manner by approximately $32 \%, 56 \%$, and $98 \%$ with deoxycholate at $0 \cdot 1,0 \cdot 5$, and $1 \cdot 0 \mathrm{mmol} / 1$, respectively (Fig 2). Similar increases in proton permeability were observed with glycodeoxycholate (Fig 3) and taurodeoxycholate (Fig 4). The unconjugated deoxycholate tended to have the most pronounced effect in increasing proton permeability.

$\mathrm{PGE}_{2}, 10^{-8}-10^{-6} \mathrm{~mol} / \mathrm{l}$, had no effect of its own on the proton permeability of duodenal brush border membrane (Fig 1). $P_{\text {net }}$ was (mean (SE)) $5 \cdot 30(0 \cdot 16)(n=12), 5 \cdot 38(0 \cdot 22)(n=9)$, and $5 \cdot 41$ $(0.21)(n=14) \times 10^{-4} \mathrm{~cm} / \mathrm{s}$ in the presence of $P G_{2}$

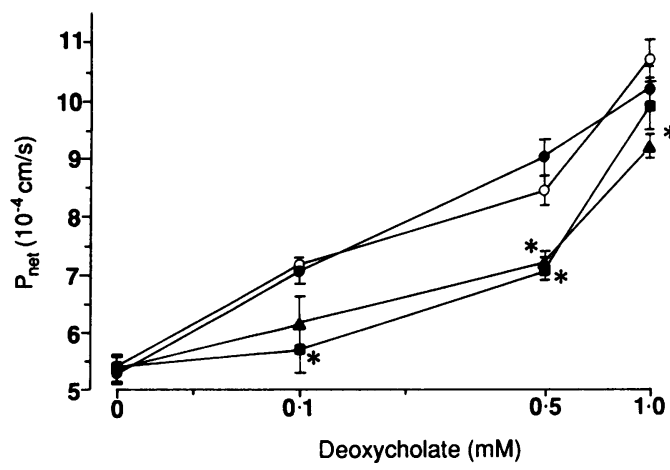

Figure 2: The effect of $P G E_{2}$ on deoxycholate induced increase in proton permeation in duodenal brush border membrane vesicles. Proton permeability $\mathrm{P}_{\text {et }}$ is plotted against the concentration of deoxycholate with and without $(O)$ pretreatment with $P G E_{2}: 10^{-8}(\mathbf{O}), 10^{-7}(\Delta)$, or $10^{-6}$ molll (匹). Results are plotted as mean values with error bars of I SE, $n=8-20 ;{ }^{\star} p<0.05$ compared with values without $P G E_{2}$.

$10^{-8}, 10^{-7}$, and $10^{-6} \mathrm{~mol} / \mathrm{l}$, respectively (Figs 2 and 3 ).

Preincubation of duodenal brush border membrane with $\mathrm{PGE}_{2}, 10^{-8} \mathrm{~mol} / \mathrm{l}$, for five minutes before the addition of any of the bile salts only significantly reduced the ability of taurodeoxycholate, $0.5 \mathrm{mmol} / 1$, to increase $P_{\text {net }}$ (Fig 4). At higher concentrations, however, $\mathrm{PGE}_{2}$ significantly reduced the bile salt induced increases in $P_{\text {net }}$. The effect of $\mathrm{PGE}_{2}, 10^{-7} \mathrm{~mol} / \mathrm{l}$, on the rate of recovery of acridine orange fluorescence quenching in the presence of $0.5 \mathrm{mmol} / 1$ deoxycholate is shown in Figure 1. $\mathrm{PGE}_{2}$ was most effective against taurodeoxycholate induced increases in $P_{\text {net }}$ (Fig 4) and least effective against glycodeoxycholate (Fig 3).

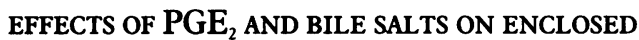
VOLUME OF DUODENAL BRUSH BORDER MEMBRANE VESICLES

The enclosed volume of untreated duodenal brush border membrane vesicles was (mean (SE) $0.533(0.011) \quad(\mathrm{n}=30) \mu \mathrm{l} / \mathrm{mg}$ protein. $\mathrm{PGE}_{2}, 10^{-8}-10^{-6} \mathrm{~mol} / \mathrm{l}$, did not influence this value; $0.494(0.015)(\mathrm{n}=10), 0.508(0.016)$ $(\mathrm{n}=8)$, and $0.517(0.022)(\mathrm{n}=16) \mu \mathrm{l} / \mathrm{mg}$ protein

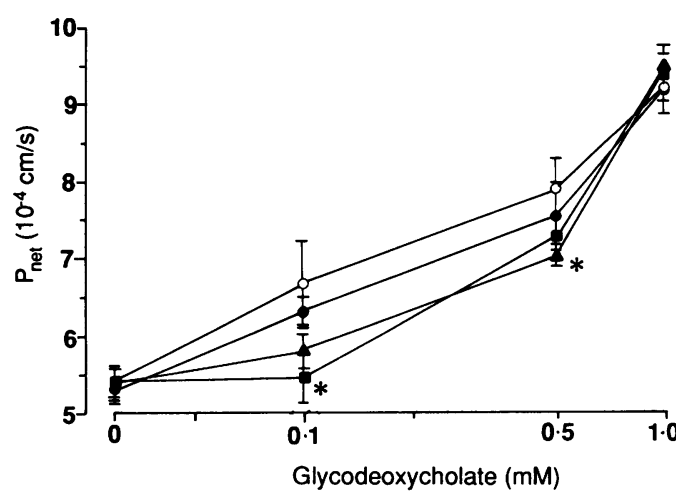

Figure 3: The effect of $P G E_{2}$ on glycodeoxycholate induced increase in proton permeation in duodenal brush border membrane vesicles. Proton permeability $P_{\text {net }}$ is plotted against the concentration of glycodeoxycholate with and without $(O)$ pretreatment with $P G E_{2}: 10^{-8}(\mathbf{O}), 10^{-7}(\Delta)$, or $10^{-6} \mathrm{~mol} / \mathrm{l}$ pretreatment with $P G E_{2}: 10^{-8}(\mathrm{O}), 10^{-7}(\mathbf{A})$, or $10^{-6} \mathrm{~mol} /$
$(\square)$. Results are plotted as mean values with error bars of I $S E, n=8-20 ;{ }^{\star} p<0.05$ compared with values without $P G E_{2}$. 
Figure 4: The effect of $P G E_{2}$ on taurodeoxycholate induced increase in proton permeation in duodenal brush border membrane vesicles. Proton permeability $P_{\text {met }}$ is plotted against the concentration of taurodeoxycholate with and without $(O)$ pretreatment with $P G E_{2}: 10^{-8}(O), 10^{-1}$ $(\Delta)$, or $10^{-6}$ molll ( $\square$ ). Results are plotted as mean values with error bars of 1 $S E, n=8-20 ;{ }^{\star} p<0.05$ compared with values without $P G E_{2}$
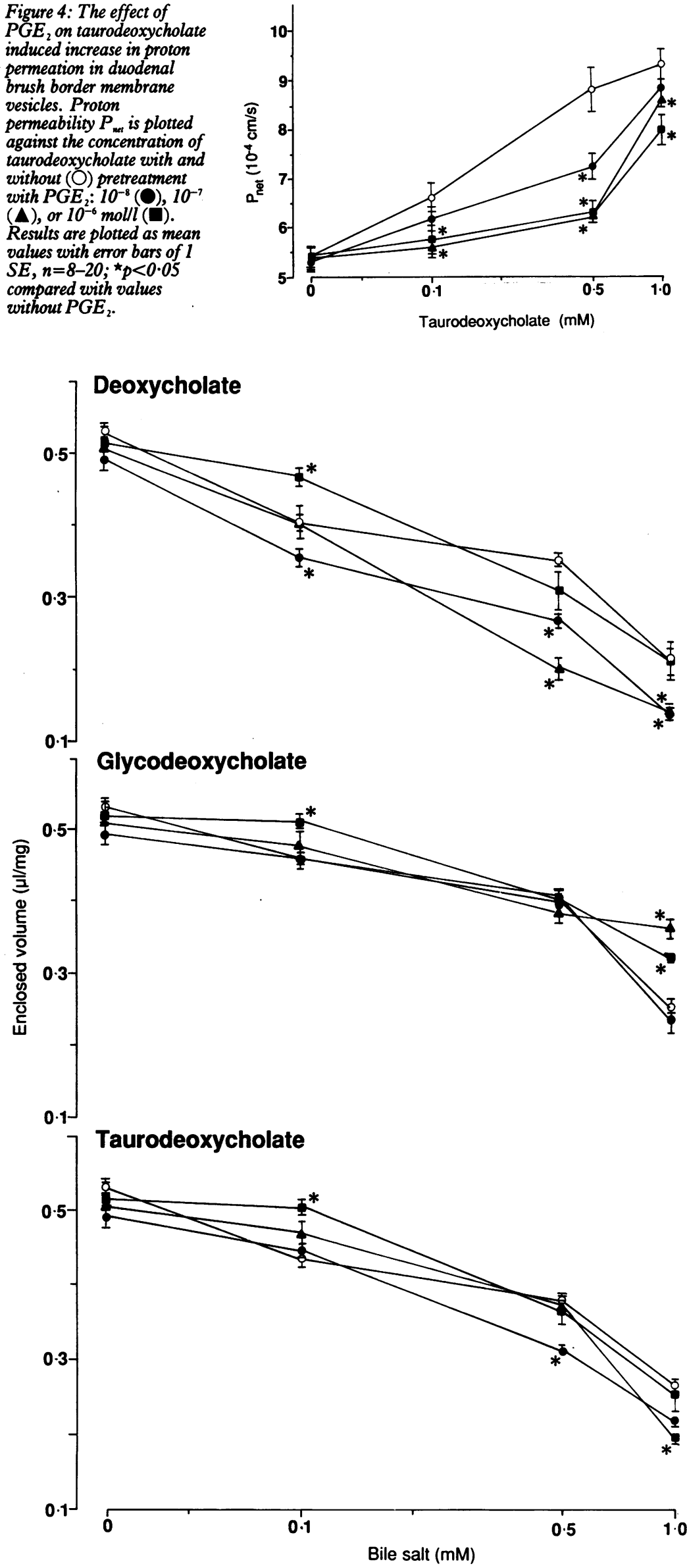

Figure 5: The effect of $P G E_{2}$ on bile salt induced decrease in duodenal brush border membrane vesicle enclosed volume. Enclosed volume $\left(\left[{ }^{14} \mathrm{C}\right]\right.$ glucose space at equilibrium $)$ is plotted against the concentration of deoxycholate, glycodeoxycholate, and taurodeoxycholate, with and without $(O)$ pretreatment with $P G E_{2}: 10^{-8}(O), 10^{-7}(\mathbf{A})$, or $10^{-6} \mathrm{~mol} / \mathrm{l}(\mathbf{\square})$. Results are plotted as mean values with error bars of $1 S E, n=8-30 ;{ }^{\star} p<0.05$ compared with values without $P G E_{2}$. with $\mathrm{PGE}_{2} 10^{-8}, 10^{-7}$, and $10^{-6}$, respectively. The three bile salts decreased vesicular enclosed volume in a concentration dependent manner (Fig 5). Preincubation of duodenal brush border membrane with $\mathrm{PGE}_{2}, 10^{-6} \mathrm{~mol} / \mathrm{l}$, inhibited the decrease in enclosed volume induced by the three bile salts at a concentration of $0.1 \mathrm{mmol} / \mathrm{l}$. $\mathrm{PGE}_{2}$ at the lower concentrations had no consistent effect on the bile salt induced reductions in enclosed volume. The exception was $\mathrm{PGE}_{2}$ at $10^{-8}$ and $10^{-7} \mathrm{~mol} / \mathrm{l}$, which significantly enhanced the reduction in enclosed volume induced by unconjugated deoxycholate (Fig 5).

\section{Discussion}

The present study provides evidence that prostaglandin exerts a direct protective action on duodenal membranes. In particular, $\mathrm{PGE}_{2}$ reduced the bile salt induced increase in membrane proton permeability. Increased proton permeability in the presence of bile salts is likely to be an early event in their damaging action, and is observed with relatively low concentrations. ${ }^{19}$ Thus, this protective effect of $\mathrm{PGE}_{2}$ is likely to be important in maintaining normal duodenal integrity. $\mathrm{PGE}_{2}$ at $10^{-6} \mathrm{~mol} / \mathrm{l}$ also had a lesser effect in preventing bile salt induced reduction in membrane vesicle integrity, as shown in the reduction in enclosed volume. Paradoxically, at the two lower concentrations $\mathrm{PGE}_{2}$ enhanced the damaging effects of unconjugated deoxycholate on membrane integrity. The reason for this last effect remains obscure.

Direct membrane protective effects of prostaglandin have been implied in other studies. A high concentration of $\mathrm{PGE}_{2}, 10^{-3} \mathrm{~mol} / \mathrm{l}$, improved cell viability after taurocholate treatment in isolated rat gastric mucosal cells. ${ }^{10}$ Similar protective effects have been observed with lower concentrations of 16,16-dimethyl $\mathrm{PGE}_{2}, 10^{-8}$ $10^{-6} \mathrm{~mol} / \mathrm{l}$, against injury induced by taurocholate, ethanol, or indomethacin in rat gastric mucosal cells in culture, human isolated gastric glands, and guinea pig isolated peptic cells. ${ }^{11-15}$ These last studies provide considerable evidence for a direct protective action of prostaglandin on gastric cells, although this conclusion has been disputed by others. ${ }^{22}$ In the liver prostacyclin prevented lysosomal and cytoplasmic enzyme release in response to hypoxic damage, suggesting a membrane stabilising effect. ${ }^{23}$ Low concentrations of $\mathrm{PGE}_{2}$ decrease erythrocyte membrane deformability. ${ }^{24}{ }^{25}$ In isolated gastric mucosal cell membranes high concentrations of taurocholate, $100 \mathrm{mmol} / \mathrm{l}$, increased the polar part of the electron spin resonance of 16-doxylstearic acid spin label, consistent with disintegration of the membranes and formation of micellar aggregates with taurocholate. ${ }^{26}$ Similar membrane dissolution has been observed with deoxycholate salts at $5 \mathrm{mmol} / \mathrm{l}$ in duodenal brush border membrane. ${ }^{19}$ The effect of taurocholate on the gastric mucosal membranes was completely prevented by preincubation with $25 \mathrm{nmol} \mathrm{PGE}_{2}{ }^{26}$ These results, considered with our own, perhaps point to some generalised membrane stabilising effects of prostaglandin, such as stabilising polar phospholipid head groups, and hence ameliorating the membrane perturbing action of damaging 
agents. In erythrocytes, however, 16,16dimethyl $\mathrm{PGE}_{2}$ was unable to alter alcohol or aspirin induced haemolysis and slightly increased haemolysis when administered alone. ${ }^{27}$ This last observation may be related to the increased fragility of duodenal brush border membrane vesicle observed with the lower concentrations of $\mathrm{PGE}_{2}$ when administered with bile salts (Fig 5).

The effects of prostaglandin in the gastrointestinal tract are diverse, with many actions which may be categorised as protective in nature. An impaired ability of the human duodenal mucosa in duodenal ulcer disease to synthesise prostaglandin has been noted in some studies. ${ }^{28} 29$ Ahlquist et al, however, reported no difference in basal prostaglandin synthesis in duodenal ulcer patients and normal controls..$^{30}$ In contrast, the normal increased prostaglandin synthesis in response to a meal was attenuated in duodenal ulcer disease, suggesting the mucosa of these patients has an impaired response to an acid load. ${ }^{30}$ The ability of $\mathrm{PGE}_{2}$ to reduce bile salt induced increases in duodenal membrane acid permeation may be one important and direct physiological mechanism for duodenal mucosal protection.

This work was supported by a grant from MRC (G8418056CA).

1 Robert A. An intestinal disease produced experimentally by a prostaglandin deficiency. Gatroenterology 1975; 69: 1045-7.

2 Starlinger M, Jakesz R, Matthews JB, Yoon C, Schiessel R. The relative importance of $\mathrm{HCO}_{3}$ - and blood flow in the protection of rat gastric mucosa during shock. Gastroenterolprotection of rat gast

3 Miller TA. Protective effects of prostaglandins against gastric mucosal damage: current knowledge and proposed mechanisms. Am $\mathcal{F}$ Physiol 1983; 245: G601-G23.

4 Allen A, Flemström G, Garner A, Silen W, Turnberg LA, eds. Mechanisms of mucosal protection in the upper gastrointestinal tract. New York: Raven Press, 1984

5 Cohen MM, ed. Biological protection with prostaglandins. Boca Raton FL: CRC Press, 1986

6 Hirst BH. The gastric mucosal barrier. In: Forte JG, ed. Handbook of physiology. The gastrointestinal system. Vol III, Gastrointestinal secretion. Bethesda MD: American Physiological Society, 1989: 279-308.

7 Guth PH, Paulsen HG, Nagata H. Histologic and microcirculatory changes in alcohol-induced gastric lesions in the rat: effect of prostaglandin cytoprotection. Gastroenterology rat: effect of prostag

8 Szabo S, Trier JS, Brown A, Schnoor J. Early vascular injury and increased vascular permeability in gastric mucosal injury caused by ethanol in the rat. Gastroenterology 1985; 88: 22836.

9 Kauffman GL. Gastric circulation. In: Cohen MM, ed. Biological protection with prostaglandins. Boca Raton FL: CRC Press, 1986: 39-44.

10 Müller-Lissner SA, Fimmel C, Sonnenberg A, Peskar B, Fischer JA, Blum AL. The effect of prostaglandins on isolated rat gastric cells. Scand f Gastroenterol [Suppl] 1981; 67: 229-32

11 Terano A, Mach T, Stachura J, Tarnawski A, Ivey KJ. Effect of 16,16 dimethyl prostaglandin $E_{2}$ on aspirin induced damage to rat gastric epithelial cells in tissue culture. $G u t$ 1984; 25: 19-25.

12 Hiraishi H, Terano A, Ota S-I, Ivey KJ, Sugimoto T. Effect of cimetidine on indomethacin-induced damage in cultured rat cells; comparison with prostaglandin. f L ab Clin Med 1986; 108: 608-15.

13 Terano A, Ota S-I, Mach T, et al. Prostaglandin protects against taurocholate-induced damage to rat gastric mucosal cell culture. Gastroenterology 1987; 92: 669-77.

14 Tarnawski A, Brzozowski T, Sarfeh IJ, et al. Prostaglandin protection of human isolated gastric glands against indomethacin and ethanol injury. $\mathcal{F}$ Clin Invest 1988; 81: 1081-9.

15 Cherner JA, Naik L, Tarnawski A, Brzozowski T, Stachura J, Singh G. Ability of prostaglandin to reduce ethanol injury to dispersed chief cells from guinea pig stomach. Am F Physiol 1989; 256: G704-14.

16 Ballard HJ, Wilkes JM, Hirst BH. Effect of alcohols on gastric and small intestinal apical membrane integrity and fluidity Gut 1988; 29: 1648-55.

17 Hirst BH, Ballard HJ, Wilkes JM, Forte JG. Gastric and smal intestinal membrane vesicle resistance to trypsin: implications for mucosal protection. In: Davison JS, Schaffer EA eds. Gastrointestinal and hepatic secretions: mechanisms and eds. Gastrointestinal and hepatic secretions: mechanisms and

18 Wilkes JM, Ballard HJ, Dryden DTF, Hirst BH. Proton permeability and lipid dynamics of gastric and duodena apical membrane vesicles. Am 7 Physiol 1989; 256: G553-62

19 Zhao D, Hirst BH. Bile salt induced increases in duodena brush-border membrane proton permeability, fluidity and fragility. Dig Dis Sci 1990; 35: 589-95.

20 Kessler M, Acuto O, Murer H, Muller M, Semenza G. A modified procedure for the rapid preparation of efficiency modified procedure for the rapid preparation of efficiency membranes. Their use of investigating some properties of membranes. Their use of investigating some properties of D-glucose and choline

21 Bradford MM. A rapid and sensitive method for the quantitation of microgram quantities of protein utilizing the principle of protein-dye binding. Anal Biochem 1976; 72: 248-54

22 Pihan G, Szabo S. Protection of gastric mucosa agains hypertonic sodium chloride by 16,16 -dimethyl prostaglan $\operatorname{din} E_{2}$ or sodium thiosulfate in the rat: evidence for decreased mucosal penetration of damaging agent. Dig Dis Sci 1989; 34: 1865-72.

23 Ruwart MJ. Protection of the liver against various damaging agents. In: Cohen MM, ed. Biological protection with pros-
taglandins. Vol II. Boca Raton FL: CRC Press, 1985: 22943.

24 Allen JE, Rasmussen H. Human red blood cells: prostaglandin $\mathrm{E}_{2}$, epinephrine, and isopoterenol alter permeability. Science $1971 ; 174: 512-3$.

25 Kury PG, Ramwell PW, McConnell HM. The effects of prostaglandins $E_{1}$ and $E_{2}$ on the human erythrocyte as monitored by spin labels. Biochem Biophys Res Commun 1974; 56: 478-83.

26 Güldütuna S, Zimmer G, Kurtz W, Leuschner U. Prostaglandin $E_{2}$ directly protects isolated rat gastric surface cel membranes against bile salts. Biochim Biophys Acta 1987; 902: 217-22.

27 Guth PH, Paulsen G, Hirabayashi K. Prostaglandin cytoprotection. Prostaglandin does not protect against aspirinprotection. Prostaglandin does not protect against aspirin- or 28: $903-7$.

28 Cohen MM. Clinical evidence for gastroduodenal protection In: Cohen MM, ed. Biological protection with prostaglandins. Vol II. Boca Raton FL: CRC Press, 1985: 137-54

29 Hillier K, Smith CL, Jewell R, Arthur MJP, Ross G Duodenal mucosa synthesis of prostaglandins in duodenal ulcer disease. Gut 1985; 26: 237-40.

30 Ahlquist DA, Dozois RR, Zinsmeister AR, Malagelada J-R. Duodenal prostaglandin synthesis and acid load in health and in duodenal disease. Gastroenterology 1983; 85: 522-8. 